\title{
Charakter PRAWNy KlaUzuli PRZECiWKo UNiKANiU OPODATKOWANIA
}

\section{Wstęp}

Podatki stanowią jedno ze źródeł dochodów budżetowych. Ponieważ wydajność fiskalna źródeł jest ograniczona, to celowo podejmuje się działania zmierzające do efektywniejszego ich wykorzystania. Zjawisko „uszczelnienia systemu podatkowego" w Polsce należy rozumieć jako przeprowadzenie szeregu czynności poprawiających skuteczność poboru należności podatkowych oraz ich egzekucji. Administracja skarbowa dąży do takiego stanu, w którym wszyscy podatnicy ponoszą przewidziany dla nich w ustawie ciężar podatkowy, a budżet państwa otrzymuje wpływy, jakie należne mu są w związku z powstałymi zobowiązaniami podatkowymi u podatników. Minister Finansów wskazuje konieczność „uszczelniania systemu podatkowego" w kontekście stale wzrastających wydatków budżetowych oraz zaistniałych strat po stronie państwa, jakie wynikają z nieprawidłowo funkcjonującego systemu poboru podatku ${ }^{1}$.

* Dr, doradca podatkowy; e-mail: rafalbernat@onet.u

${ }^{1}$ Minister Finansów, [w:] Zadania Urzędów Kontroli Skarbowej na rok 2014 (wyciąg), s. 4, http://www.mf.gov.pl/documents/764034/928259/Wyci\%C4\%85g+z+zada\%C5\%84+ur z\%C4\%99d\%C3\%B3w+kontroli+skarbowej+na+rok+2014 [dostęp: 24.07 .2016 r.]; Działania zwiększające stopień przestrzegania przepisów podatkowych i poprawiające efektywność administracji podatkowej w latach 2014-2017, www.mf.gov.pl/documents/764034/1161625/ Pakiet+dzialan+podatkowych.doc [dostęp: 24.07.2016 r.]. Także Rada Ministrów, Wieloletni Plan Finansowy Państwa na lata 2016-2019, Warszawa, kwiecień 20146, s. 64, file://C:/Users/ rafber/Downloads/2_RM-111-53-16__pos__uchw_nr_49_RM_z_2016_r__WPFP_20162019_-_zal_.pdf [dostęp: 20.07.2016 r.].

W literaturze używa się również określenia „uszczelnienie systemu podatkowego". Przykładowo, M. Kowalczyk, Prawo podatkowe - wróg czy sprzymierzeniec przedsiębiorcy, 
Dążenie do perfekcyjnie funkcjonującego systemu podatkowego jest przejawem determinacji administracji skarbowej w pozyskaniu nowych środków finansowych i przedstawiane bywa jako remedium na różne problemy społeczne (np. gdyby „uszczelniono system podatkowy” byłoby więcej środków na kulturę, naukę, wspieranie wielodzietnych rodzin). Przeciwnikami takiego procesu są zazwyczaj sami podatnicy, którzy, wykorzystując luki prawne, brak przejrzystych przepisów podatkowych, tworzą skomplikowane mechanizmy zmniejszające ich obciążenie podatkowe. Pośród podatników można jednak zauważyć dwie grupy podmiotów. Pierwsza, która korzysta z optymalizacji podatkowej (i ją popiera) oraz druga - najczęściej osoby fizyczne, które, nie stosując żadnej z metod na zmniejszenie opodatkowania, mogą być przekonane o niesprawiedliwym opodatkowaniu (w porównaniu do przedstawicieli pierwszej grupy). W Polsce można zaobserwować poparcie społeczne ${ }^{2}$ dla działań władzy ustawodawczej, zmierzających do obciążenia podmiotów (zwłaszcza zagranicznych) o dużych zasobach finansowych, większym ciężarem podatkowym. Pojawia się jednak problem, jakie przepisy wprowadzić, aby uniemożliwić optymalizację podatkowa, mając na względzie to, że zjawiska gospodarcze zachodzą zazwyczaj dynamicznie i przepisy w związku z tym mogą szybko ulec dezaktualizacji. Ustawodawca podatkowy, regulując wprost opodatkowanie czynności będącej przedmiotem optymalizacji nie ma pewności, że podatnicy nie będą podejmować prób obejścia prawa poprzez modyfikacje zamierzonej czynności prawnej. Dlatego też zasadne jest wprowadzenie przepisów obejmujących swoim zakresem jak najszerszy katalog czynności optymalizacyjnych, zawierających klauzule generalne i zwroty niedookreślone, co umożliwia (w drodze uznania) rozstrzyganie przez organ podatkowy o tym, czy czynność podatnika jest przejawem unikania opodatkowania.

Dnia 15 lipca 2016 r. weszły w życie przepisy zmieniające ustawę Ordynacja podatkowa ${ }^{3}$, wprowadzające klauzulę przeciwko unikaniu opo-

"Zeszyty Naukowe Uniwersytetu Szczecińskiego nr 864. Finanse, rynki finansowe, ubezpieczenia" 2015, nr 76, t. 1, s. 19; A. Krajewska, P. Krajewski, Rozkład obciażeń podatkowych w Polsce, "Acta Universitatis Lodziensis. Folia Oeconomica” 2011, nr 248, s. 255; A. Radwan, Podatki w rolnictwie i leśnictwie - przewidywane kierunki zmian, "Folia Universitatis Agriculturae Stetinensis" 2007, nr 49, s. 155.

${ }^{2}$ Zob. Komunikat z badań CBOS. Jakie podatki chcieliby płacić Polacy? Warszawa, kwiecień 2008, s. 3, http://www.cbos.pl/SPISKOM.POL/2008/K_057_08.PDF [dostęp: 25.07.2016 r.]; Komunikat z badań CBOS. Postawy wobec płacenia podatków, Warszawa czerwiec 2016, s. 2-4, http://www.cbos.pl/SPISKOM.POL/2016/K_085_16.PDF [dostęp: 25.07.2016 r.].

${ }^{3}$ Ustawa z dnia 13 maja 2016 r. o zmianie ustawy - Ordynacja podatkowa oraz niektórych innych ustaw, Dz. U. poz. 846. 
datkowania i ustanawiające szczególną formę postępowania w przypadku unikania opodatkowania. Jest to regulacja dawno zapowiadana przez Ministra Finansów, z którą administracja skarbowa zdaje się wiązać duże nadzieje (w zakresie pozyskania znacznych środków). Przeciwdziałanie unikaniu opodatkowania ma bezpośredni wpływ na „uszczelnienie systemu podatkowego" w Polsce i zmniejszenie straty finansowej spowodowanej nieefektywnym procesem poboru podatków i egzekucji zaległości podatkowych. Powstaje pytanie, czy wprowadzenie art. 119a-119zf Ordynacji podatkowej ${ }^{4}$ przyniesie zamierzony rezultat $\mathrm{w}$ postaci zwiększenia wpływów budżetowych czy też raczej uczyni polski system podatkowy bardziej represyjnym wobec wszystkich podatników (także tych rozliczających się prawidłowo). Celem artykułu jest zatem przedstawienie charakteru prawnego ww. przepisów oraz związanych z tym niektórych zagrożeń, jakie dla podatników (oraz ich interesu ${ }^{5}$ ) mogą wynikać z wprowadzenia wspomnianych zmian w OP. Warto odnieść się do wszelkich zwrotów niedookreślonych, klauzul generalnych oraz ogólnych sformułowań użytych w przedmiotowych przepisach. Publikacja naukowa wydaje się odpowiednią formą prezentacji poglądów dotyczących klauzuli przeciwko unikaniu opodatkowania oraz przepisów odnoszących się do postępowania w sprawach unikania opodatkowania, mając na względzie możliwy wpływ nowych regulacji na status podatnika oraz brak orzecznictwa sądów administracyjnych i interpretacji indywidualnych dotyczących art. 119a-119zf OP. Co prawda, koncepcja klauzuli przeciwko unikaniu opodatkowania była przedmiotem rozważań przedstawicieli doktryny prawa podatkowego ${ }^{6}$, to jednak treść przepisów dotyczących tej

${ }^{4}$ Ustawa z dnia 29 sierpnia 1997 r. - Ordynacja podatkowa, Dz. U. z 2015 r. poz. 613 [dalej: OP].

${ }^{5}$ Pojęcie „interesu podatnika” związane jest z powstaniem korzyści po jego stronie - poszerzenie praw lub zmniejszenie obowiązków w zakresie należności publicznoprawnych. Szerzej zob. R. Bernat, Deregulacja zawodu doradcy podatkowego jako naruszenie interesu podatnika, „Studia Prawno-Ekonomiczne” 2014, t. 93, s. 18-19.

${ }^{6}$ A. Olesińska, Klauzula ogólna przeciw unikaniu opodatkowania, Toruń 2013, s. 31 i n.; P. Karwat, Obejście prawa podatkowego, Warszawa 2003, s. 124; M. Kalinowski, Granice legalności unikania opodatkowania w polskim systemie podatkowym, Toruń 2001, s. 31; A. Wrzesińska-Nowacka, Granice między unikaniem opodatkowania a uchylaniem się od niego na tle wybranych orzeczeń sądów administracyjnych, [w:] M. Münnich, A. Zdunek (red.), Stanowienie i stosowanie prawa podatkowego w Polsce. Optymalizacja podatkowa a obejście prawa podatkowego, Lublin 2012, s. 173; B. Brzeziński, Zagadnienie konstytucyjności klauzuli normatywnej zapobiegającej unikaniu opodatkowania, [w:] P. Kardas, T. Sroka, W. Wróbel (red.), Państwo prawa i prawo karne. Księga jubileuszowa Profesora Andrzeja Zolla, Warszawa 2012, s. 685; A. Kostecki, Klauzule generalne zapobiegania obejścia prawa podatkowego w niemieckiej doktrynie i regulacjach prawnych, [w:] W. Miemiec (red.), Ksiega jubileuszowa profesora Ryszarda Mastalskiego. Stano- 
klauzuli ulegała sukcesywnym zmianom. Aktualny kształt ww. przepisów OP bez wątpienia będzie mieć istotny wpływ na system opodatkowania podatników w Polsce, dlatego też zasadne jest szczegółowe zbadanie charakteru prawnego regulacji prawnych w tym zakresie.

\section{Klauzula przeciwko unikaniu opodatkowania}

Zgodnie z konstytucyjną zasadą każdy jest obowiązany do ponoszenia ciężaru podatkowego, którego charakter ma podstawę ustawową (art. 84 i 217 Konstytucji RP). Jest to jednak zasada, która bywa różnie rozumiana w zależności od tego, czy ciężar ten opisuje organ podatkowy czy też podatnik. Prawdą jest, że dotychczas nie wprowadzono do polskiego porządku prawnego przepisu, który nakazywałby nakładać na podatnika najwyższe możliwe obciążenie podatkowe w sytuacji gdy zaistnieje wątpliwość co do wielkości ciężaru podatkowego 7 . Dla podatnika naturalnym rozwiązaniem wydaje się sytuacja, w której jak największą część dochodu oraz środków finansowych pozostawia się do jego wyłącznej dyspozycji, zaś jak najmniejszą część oddaje de facto na rzecz państwa. Podatnik zapewne będzie podejmował próby, których skutkiem ma być zmniejszenie

wienie i stosowanie prawa podatkowego, Wrocław 2009, s. 257. Przedmiotem rozważań autora nie są obowiązujące $\mathrm{w}$ przeszłości przepisy odnoszące się do unikania opodatkowania. W tym zakresie należy odesłać do: D. Mączyński, Wpływ orzecznictwa Trybunału Konstytucyjnego na trwałość instytucji materialnego prawa podatkowego, „Ruch Prawniczy, Ekonomiczny i Socjologiczny" 2014, z. 3, s. 27-29. W doktrynie prawa podatkowego posługiwano się określeniem „klauzula ogólna”; „klauzula normatywna” zapobiegania unikania opodatkowania - np. A. Olesińska, Konstrukcja i funkcjonowanie klauzuli ogólnej zapobiegającej unikaniu opodatkowania w prawie podatkowym Kanady, „Kwartalnik Prawa Podatkowego” 2010, nr 2, s. 63; B. Brzeziński, A. Olesińska, Klauzula normatywna zapobiegania unikaniu opodatkowania, [w:] B. Brzeziński (red.), Prawo podatkowe. Teoria, instytucje, funkcjonowanie, Toruń 2009, s. 289. W kontekście nowelizacji OP i wprowadzenia „klauzuli przeciwko unikaniu opodatkowania" należy uwagę zwracać na treść art. 119a-119zf i ich skutek na przyszłość, a nie na różnice tautologiczne dotyczące tej materii.

7 Także S. Bryndziak, Nadużywanie przepisów umów o unikaniu podwójnego opodatkowania przez transfer rezydencji podatkowej, „Zeszyty Naukowe Uniwersytetu Szczecińskiego nr 818. Finanse, rynki finansowe, ubezpieczenia" 2014, nr 68, s. 42. Dlatego też między administracją skarbową a podatnikami toczy się nieustanny spór o wysokość ciężaru podatkowego. Tak A. Gomułowicz, Aspekty ustrojowe opodatkowania, [w:] T. Dobrowska-Romanowska, A. Jankiewicz (red.), Konstytucja, ustrój, system finansowy państwa. Księga pamiatkowa ku czci prof. Natalii Gajl, Warszawa 1999, s. 370 i A. Napiórkowska, Czy ktoś broni podatnika?, „Studia Finansowoprawne", red. P. Borszkowski, A. Huchla, E. Rutkowska-Tomaszewska, Podatnik versus organ podatkowy, 2011, nr 2, s. 147-150. 
opodatkowania ciążącego na nim. Przedstawiciele administracji skarbowej będą zaś kwestionowali czynności cywilnoprawne zmierzające do obniżenia wysokości podstawy opodatkowania, stawki podatkowej lub samego podatku ${ }^{8}$. Trudno jednak wyznaczyć granicę pomiędzy przeprowadzaniem czynności zgodnej z zamiarem stron a dokonywaniem transakcji (bez ekonomicznego uzasadnienia), których wyłącznym celem jest optymalizacja podatkowa. Klauzula przeciwko unikaniu opodatkowania wydaje się służyć kwestionowaniu czynności prawnych, których treść kształtowana jest sztucznie, mając na względzie wyłącznie zysk podatkowy ${ }^{9}$. Przyczyna, a także planowane skutki wprowadzenia tej klauzuli wydają się być zgodne z realizacją zasady powszechności opodatkowania oraz praworządności. Podatek jest daniną powszechna z z której zwolnienie (wyłączenie) powinno mieć podstawę ustawową. Warto jednak zauważyć, że także krytyczna ocena realizacji przez podatnika metody samoobliczenia podatku oraz podnoszenie przez organ pozorności dokonywanych czynności prawnych musi być sprecyzowane $\mathrm{w}$ akcie normatywnym o randze ustawy. Mając na względzie ten wymóg, ustawodawca wprowadził zmiany w zakresie prawa podatkowego materialnego, proceduralnego oraz postępowania sądowoadministracyjnego (art. 1-9 powołanej wyżej ustawy z dnia 13 maja 2016 r. o zmianie ustawy - Ordynacja podatkowa oraz niektórych innych ustaw).

Treść artykułu 119a § 1 OP zawiera przesłanki kwalifikacji czynności (w ramach szerokiego katalogu), które są przejawem unikania opodatkowania $^{10}$. Wskazane $\mathrm{w}$ przepisie kryteria mogą sprawić, że podatnicy będą obawiać się dokonywania czynności prawnych jako potencjalnie wątpli-

8 Zob. H. Litwińczuk, Obejście prawa podatkowego w świetle doświadczeń międzynarodowych, "Przegląd Podatkowy” 1999, nr 9, s. 3; K. Raczkowski, A. Krukowski, Optymalizacja podatkowa w teorii i praktyce zarzadzania wiedza bezpieczeństwa ekonomicznego, „Monitor Prawa Celnego i Podatkowego" 2010, nr 8, s. 279-281.

9 Zob. M.M. Hybka, Możliwości zapobiegania agresywnemu planowaniu finansowego, „Kwartalnik Kolegium Ekonomiczno-Społecznego. Studia i Prace” 2015, nr 3, t. 4, s. 123125. Warto jednak zwrócić uwagę, że klauzula może być postrzegana przez podatników jako stricte narzędzie realizujące funkcję fiskalną podatków, choćby organy podatkowe uzasadniały jej wprowadzenie potrzebą realizacji funkcji pozafiskalnych. O problemie pozornego działania (w tej materii) ustawodawcy podatkowego i organów podatkowych wspomina W. Modzelewski (red.), Wstęp do nauki polskiego prawa podatkowego, Warszawa 2010, s. 26.

${ }^{10}$ M. Gordon, Klauzula przeciwko unikaniu opodatkowania w założeniach projektu zmiany Ordynacji podatkowej z kwietnia 2014 roku, „Roczniki Naukowe Wyższej Szkoły Bankowej w Toruniu" 2013, nr 12, s. 213-215. 
wych dla organów podatkowych. Warto zgodzić się z poglądem ${ }^{11}$, że instytucja klauzuli przeciwko unikaniu opodatkowania powinna być stosowana wyjątkowo, gdy inne, ordynaryjne środki zapobiegające nielegalnej optymalizacji podatkowej nie przynoszą rezultatów. Organ podatkowy posiada szereg instrumentów, dzięki którym niewłaściwie ustalona podstawa opodatkowania może zostać skorygowana (art. 23; art. 272 pkt 4 OP; art. 6 ust. 4 ustawy o podatku od czynności cywilnoprawnych; art. 14 ust. 3 ustawy o podatku dochodowym od osób prawnych; art. 19 ust. 4 ustawy o podatku dochodowym od osób fizycznych ${ }^{12}$ ). Być może wprowadzenie klauzuli spowoduje zmniejszenie liczby postępowań dowodowych w ramach procedury podatkowej, kiedy to organ musi zgromadzić pełen materiał dowodowy, aby sformułować zarzut pozorności transakcji. Kwalifikacja przeprowadzanych przez podatnika czynności prawnych jako tych określonych $\mathrm{w}$ art. 119a § 1 OP nie gwarantuje tego, że strona będzie mogła korzystać z domniemania prawdziwości składanego przed organem oświadczenia ${ }^{13}$.

Mając na względzie możliwości kontrolne administracji skarbowej istotne są także wyłączenia ustawowe, w przypadku których art. 119a OP dotyczący unikania opodatkowania nie ma zastosowania. Wyłączenia te mają charakter podmiotowy (podmiot posiadający opinię zabezpieczającą lub którego wniosek o taką opinię nie został rozpatrzony w odpowiednim terminie) i przedmiotowy (korzyść podatkowa nie przekracza 100000 zł, w odniesieniu do VAT, opłat i należności budżetowych). W stosunku do wyłączenia podatku od wartości dodanej w art. 119a OP podnosi się ${ }^{14}$,

11 Tak L. Etel (red.), Ordynacja podatkowa. Kierunkowe założenia nowej regulacji, Białystok 2015, s. 280. Podobnie J. Szczepański, Unikanie opodatkowania w świetle orzecznictwa niemieckiego, „Ruch Prawniczy, Ekonomiczny i Socjologiczny” 2014, z. 1, s. 106. Jak słusznie zauważa H. Litwińczuk, klauzula ta jest jedynie jedną z form zwalczania zjawiska unikania opodatkowania - jednak najbardziej skuteczną (H. Litwińczuk, [w:] G. Gołębiowski, H. Dzwonkowski (red.), Zmiany w Ordynacji podatkowej. Poprawa jakości i uproszczenia. Konferencja, Warszawa 2013, s. 32).

12 Ustawa z dnia 9 września 2000 r. o podatku od czynności cywilnoprawnych, Dz. U. z 2016 r. poz. 223); ustawa z dnia 15 lutego 1992 r. o podatku dochodowym od osób prawnych, Dz. U. z 2014 r. poz. 851; ustawa z dnia 26 lipca 1991 r. o podatku dochodowym od osób fizycznych, Dz. U. z 2012 r. poz. 361.

13 Tak A. Mariański, Rozstrzyganie wattpliwości na korzyść podatnika. Zasada prawa podatkowego, Warszawa 2011, s. 172 i n.; J. Duży, Zorganizowana przestępczość podatkowa w Polsce. Zwalczanie przestępnego nadużycia mechanizmów podatków VAT i akcyzowego, Warszawa 2013, s. 125.

14 Kierunkowe założenia nowej Ordynacji podatkowej przygotowane przez Komisję kodyfikacyjną Ogólnego prawa podatkowego, Warszawa, dnia 11 marca 2015 r., s. 146, 
że wynika to $\mathrm{z}$ faktu występowania $\mathrm{w}$ orzecznictwie unijnym zasady zakazu nadużycia prawa, która ma być substytutem dla klauzuli przeciwko unikaniu opodatkowania. Należy przy tym wspomnieć o odwołaniu (art. 119b § 2 OP) do umów o unikaniu podwójnego opodatkowania, w których występują niekiedy podobne klauzule. Jednakże stopień skomplikowania postanowień dotyczących unikania opodatkowania jest znacznie mniejszy w umowach pomiędzy państwami umawiającymi się (niż w Ordynacji podatkowej) ${ }^{15}$. Oznacza to, że czasami czynność nieuznana w świetle postanowień pojedynczej umowy bilateralnej jako pozbawiona ekonomicznego uzasadnienia i dokonana $\mathrm{w}$ celu obejścia prawa podatkowego będzie kwalifikowana zgodnie $\mathrm{z}$ art. 119a § 1 OP. Tym samym, polski ustawodawca wprowadza klauzulę wyrażoną w sposób bardziej precyzyjny niż ma to miejsce zwyczajowo w umowach o unikaniu podwójnego opodatkowania, których stroną jest Polska.

Biorąc pod uwagę wyłączenie kwotowe dotyczące korzyści podatkowych poniżej kwoty 100000 zł zachodzi prawdopodobieństwo, że podatnicy będą podejmować próby podziału zamierzonej transakcji na wiele poszczególnych czynności, których wartość nie przekracza kwoty wymienionej $\mathrm{w}$ art. 119b § 1 pkt 1 OP. Dokonując skomplikowanych operacji kapitałowych (np. transgraniczne restrukturyzacje spółek handlowych), planowanie podatkowe jest podstawą przeprowadzenia prawidłowego przedsięwzięcia ${ }^{16}$, dlatego też nie można wymagać od podatnika, że z powodu obawy sformułowania przez organ zarzutu unikania opodatkowania odstąpi od porównania różnych solucji prawnych w kontekście ich skutków podatkowych. Wraz z wprowadzeniem klauzuli przyjęto kategoryzację planowania podatkowego na czynności mające uzasadnienie ekonomiczne oraz dokonywane w sposób sztuczny. Zgodnie

http://www.mf.gov.pl/documents/766655/3244380/Kierunkowe+zalozenia+Ordynacji+Po datkowej.pdf [dostęp: 20.07.2016 r.]

${ }^{15}$ Przykładowo: art. 23 umowy między Rzecząpospolitą Polską a Republiką Chorwacji w sprawie unikania podwójnego opodatkowania w zakresie podatków od dochodu i majątku, sporządzona w Warszawie dnia 19 października 1994 r., Dz. U. z 1996 r. Nr 78, poz. 370; art. 23 Konwencji między Rzecząpospolitą Polską a Królestwem Niderlandów w sprawie unikania podwójnego opodatkowania i zapobiegania uchylaniu się od opodatkowania $\mathrm{w}$ zakresie podatków od dochodu, podpisana w Warszawie dnia 13 lutego 2002 r., Dz. U. z 2003 r. Nr 216, poz. 2120.

16 Tak I. Maj, Unikanie opodatkowania w korporacjach międzynarodowych, [w:] M. Sadowski, A. Spychalska, K. Sadowa (red.), Acta Erasmiana VI. Ze studiów nad prawem, administracja i ekonomia, Wrocław 2014, s. 387-389; A. Spoz, Wybrane metody optymalizacji podatkowej przedsiębiorstw, "Zeszyty Naukowe Uniwersytetu Szczecińskiego. Finanse, rynki finansowe, ubezpieczenia" 2012, nr 52, s. 241-243; J. Wyciślok, Optymalizacja podatkowa. Legalne zmniejszanie obciążeń podatkowych, Warszawa 2013, s. 1-3. 
z art. 119c OP sztuczny charakter czynności ocenia się przez pryzmat nieuzasadnionych modyfikacji operacji, powiązań stron transakcji i ryzyka ekonomicznego, jakie związane jest z planowaną operacją gospodarczą. Dokonując weryfikacji tych determinantów uznania czynności za „sztuczną" organ podatkowy korzysta z ogólnych zasad, opisanych przez ustawodawcę przy użyciu zwrotów niedookreślonych - "podmiot działający rozsądnie", "zgodne z prawem cele", „spodziewane korzyści inne niż podatkowe". Wydaje się, że dopiero w przyszłości powstanie pewna praktyka interpretowania tych pojęć $\mathrm{w}$ formie wydawanych i upublicznianych opinii zabezpieczających oraz orzecznictwa sądów administracyjnych, które będą orzekać w sprawach ze skarg określonych w art. $119 y$ \& 3, art. 119 lit. za pkt 3 OP.

Także przy określaniu „korzyści podatkowej” zdecydowano się na użycie ogólnego opisu. Wedle art. 119e OP korzyścią podatkową jest nie tylko pomniejszenie podstawy opodatkowania, wymiaru podatku, ale także niepowstania zobowiązania podatkowego. Korzyść podatkowa istnieje także wtedy, gdy podatnik dokonuje czynności w taki sposób, aby nie były one objęte zakresem przedmiotowym opodatkowania. Treść art. 119 OP jest zgodna z ugruntowaną linią interpretacyjną dotyczącą tego zagadnienia ${ }^{17}$. Wydaje się, że podstawą określenia granic „korzyści podatkowej” była potrzeba realizacji zasady powszechności opodatkowania. Dodatkowo, czynności można kwalifikować jako podjęte w celu osiągnięcia korzyści podatkowej także wtedy, gdy podatnik nie jest w stanie wykazać, że np. mniejszy ciężar podatkowy związany był przede wszystkim z celami ekonomicznymi lub gospodarczymi (art. 119d OP).

Dokonując oceny rozwiązań przyjętych w art. 119a-119zf OP, należy zwrócić uwagę na dużą liczbę zwrotów niedookreślonych, definicji określonych w sposób ogólnikowy, odnoszenie się do pojęć nieostrych ${ }^{18}$. Jest to

17 Zob. wyrok WSA w Poznaniu z 7 czerwca 2006 r. (I SA/Po 121/04); wyrok WSA w Warszawie z 5 marca 2010 r. (III SA/Wa 1545/09); wyrok WSA w Szczecinie z 6 lipca 2016 r. (I SA/Sz 475/16); wyrok WSA w Łodzi z 10 czerwca 2016 r. (III SA/Łd 165/16); wyrok WSA w Gdańsku z 19 kwietnia 2016 r. (I SA/Łd 16/16); wyrok WSA w Białymstoku z 18 kwietnia 2016 r. (I SA/Bk 1255/15); wyrok WSA w Gliwicach z 18 kwietnia 2016 r. (I SA/Gl 1045/15); wyrok WSA we Wrocławiu z 4 marca 2016 r. (I SA/Wr 14/16); wyroki NSA z 6 kwietnia 2011 r. (I FSK 523/10) i 14 czerwca 2016 r. (I FSK 1611/14); CBOSA.

${ }^{18} \mathrm{Z}$ uwagi na zakres przedmiotowy artykułu, w odniesieniu do systematyki pojęć nieostrych, zwrotów niedookreślonych należy odwołać się do: A. Choduń, A. Gomułowicz, A. Skoczylas, Klauzule generalne i zwroty niedookreślone w prawie podatkowym i administracyjnym. Wybrane zagadnienia teoretyczne i orzecznicze, Warszawa 2013. Jednocześnie wydaje się, że art. 119a-119zf OP są przykładem prawidłowej legislacji podatkowej, gdyż ustawodawca nie tylko określił charakter czynności kwalifikowanych jako unikanie opodatkowania, ale 
celowe działanie ustawodawcy, który chciał nadać Ministrowi Finansów efektywne narzędzie do przeciwdziałania nieuczciwym praktykom podatników unikających przewidzianego prawem obciążenia podatkowego. Przyjęto kwotę 100000 zł jako minimalną wartość korzyści podatkowej, jaką podatnik może osiągnąć, aby zastosowanie miały przepisy dotyczące ww. klauzuli. Minister Finansów jednak nie jest w stanie skontrolować lub wszcząć postępowanie wobec wszystkich podatników, dokonujących czynności prawnych związanych z korzyścią o takiej wartości. Wynika to $\mathrm{z}$ braku zasobów ludzkich w ramach organów podatkowych oraz środków finansowych, jakie należałoby przeznaczyć na działania w trybie art. $119 \mathrm{~g}$ i n. OP. Przyjęcie tego typu wartości musi zatem pełnić funkcję prewencyjną. Wypełnianie innych funkcji klauzuli o unikaniu opodatkowania (sankcyjna, fiskalna) uzależnione jest w dużej mierze od charakteru postępowania określonego $\mathrm{w}$ art. 119 lit. g-119 lit. 1 OP.

\section{Postępowanie podatkowe w przypadku unikania opodatkowania}

Wprowadzenie klauzuli przeciwko unikaniu opodatkowania wymagało szczególnego procedowania organów podatkowych. Trudno bowiem wymagać od pracowników każdego urzędu obsługującego organ podatkowy I instancji, aby wraz z wprowadzeniem nowelizacji w OP automatycznie stali się specjalistami ${ }^{19} \mathrm{~W}$ zakresie odróżniania przejawów unikania opodatkowania od standardowego dokonywania czynności prawnej, przy jednoczesnym marginalnym ciężarze podatkowym. Jest to proces

także uregulował postępowanie w sprawie klauzuli, kwestie opinii zabezpieczającej czy też kształt Rady. Dodatkowo, nie można podnosić zarzutu, że nowelizacja została wprowadzona nagle, bez przeprowadzenia szeroko pojętych działań konsultacyjnych. W odniesieniu do innych zmian podatkowych oraz skutków popełnionych błędów legislacyjnych wypowiada się słusznie M. Duda, Uwarunkowania i zakres nowelizacji ustawy o podatku od towarów i ustug w dobie kryzysu finansowego, „Studia Prawnicze KUL” 2014, nr 2, s. 43-45.

${ }_{19}$ Wprowadzenie nowych, istotnych przepisów powoduje, że urzędnicy organów podatkowych muszą uaktualnić stan swojej wiedzy i niekiedy nabyć nowe umiejętności w wykonywanej pracy; zob. A. Tołwińska, Zarzadzanie wiedza w urzędach kontroli skarbowej $z$ punktu widzenia sprawnej ochrony interesów fiskalnych państwa, "Ekonomia i Zarządzanie" 2015, nr 1, s. 220-221. Rozpatrywanie działań podatnika pod kątem ich kwalifikacji jako metod unikania opodatkowania wymaga wysokich kwalifikacji w zakresie dokonywanej wykładni przepisów podatkowych. Większość zaś pracowników administracji skarbowej nie ma wykształcenia prawniczego; tak M. Kaliński, Rozwój zasobów ludzkich w administracji podatkowej, "Zarządzanie Zasobami Ludzkimi” 2011, nr 5, s. 52-54. 
wymagający szerokiej wiedzy prawniczej (zwłaszcza w zakresie prawa cywilnego, handlowego) jak i znajomości metod optymalizacyjnych, wykorzystywanych w praktyce przez podatników. Wydaje się, że zwłaszcza samorządowe organy podatkowe I instancji, w których pracownicy odpowiedzialni za zagadnienia podatkowe pełnią także inne funkcje w urzędzie (np. specjalista ds. zamówień publicznych) mogłyby nie sprostać wyzwaniom związanym z wprowadzeniem klauzuli. Słusznie zatem ustalono, że Minister Finansów wszczyna postępowanie podatkowe (kontrolne) lub staje się organem właściwym w postępowaniu już prowadzonym, jeśli może być wydana decyzja z zastosowaniem art. 119a OP. Jeśli sprawa podatkowa odnosi się do podatków lokalnych, działanie Ministra Finansów uzależnione jest od wniosku organu podatkowego I instancji. Minister Finansów, przejmując toczące się postępowanie (stając się organem właściwym) nadaje mu nowy charakter, jednocześnie utrzymując w mocy wszelkie ustalenia poczynione przez organ prowadzący dotychczas sprawę (zob. art. 119g § 5 OP). Postępowanie może zostać przejęte przez Ministra Finansów jedynie w części, czego skutkiem będzie dalsze prowadzenie postępowania przez dotychczasowy organ podatkowy lub organ kontroli skarbowej. Nie oznacza to jednak, że charakter przejętego postępowania zależy jedynie od Ministra Finansów - może on wystąpić o opinię Rady do Spraw Przeciwdziałania Unikaniu Opodatkowania ${ }^{20}$. Uprawnienie do wystąpienia o opinię Rady może zostać zrealizowane $e x$ cathedra bądź bezpośrednio na wniosek strony postępowania.

Rozpatrując wniosek o wydanie opinii, Rada posiada prawo do pozyskiwania (od Ministra Finansów lub strony) informacji niezbędnych do prawidłowego procedowania. Nie można przyrównać statusu Rady do organu podatkowego, gdyż jest to ciało doradcze (kolegialne) mające wydać opinie (a nie rozstrzygać sprawę in concreto) - a contrario art. 113 i 113a OP. W piśmiennictwie ${ }^{21}$ wymienia się cechy organu podatkowego

20 Dalej: Rada.

${ }^{21}$ J. Kunysz, Wójt, burmistrz, prezydent miasta jako organ podatkowy (wybrane zagadnienia), „Administracja: Teoria, Dydaktyka, Praktyka”" 2012, nr 2, s. 59-61; C. Kosikowski, [w:] C. Kosikowski, L. Etel, R. Dowgier, Ordynacja podatkowa. Komentarz, Warszawa 2009, s. 99; J. Małecki, [w:] A. Gomułowicz, J. Małecki, Podatki i prawo podatkowe, Warszawa 2010, s. 364. K. Teszner dodatkowo wymienia cechy: władztwo podatkowe, działanie w imieniu związku publicznoprawnego, wyodrębnienie organizacyjne $\mathrm{w}$ ramach administracji publicznej (K. Teszner Administracja podatkowa i kontrola skarbowa w Polsce, Warszawa 2012, s. 54-56). Fakt, że obsługę prac Rady zapewnia Minister Finansów, wydatki Rady są pokrywane z budżetu państwa, a do członków Rady stosuje się odpowiednio art. $130 \S 1$ $\mathrm{OP}$, nie uzasadnia kwalifikacji Rady jako organu podatkowego, podlegającego Ministrowi Finansów. 
tj. uprawnienie do kontroli, poboru podatków oraz dysponowania środkami wpłacanymi przez podatników oraz realizację innych ustawowo przewidzianych zadań. Katalog organów podatkowych wskazany w art. 13 OP (także w art. 5 ust. 1 ustawy o urzędach i izbach skarbowych ${ }^{22}$ ) należy uznać za zamknięty, przez co dokonywanie wykładni rozszerzającej przepisów dotyczących właściwości organów podatkowych byłoby istotnym błędem. Wedle literalnego brzmienia art. 119m i 119t OP „Rada jest niezależnym organem", opiniującym zasadność zastosowania art. 119a OP w indywidualnych sprawach, której stanowisko zostaje później upubliczniane. Wydaje się zatem niemożliwe występowanie do Rady z wnioskiem o wydanie opinii w zakresie problemów abstrakcyjnych bądź zagadnień właściwych dla pewnych grup społeczeństwa. Skoro postępowanie podatkowe/kontrolne przejęte przez Ministra Finansów toczy się w sprawie, gdzie określono stronę, to także opinia odnosi się do jednostkowego przypadku konkretnego podmiotu (lub sprecyzowanych podmiotów).

Przed Radą może występować bezpośrednio strona, przedstawiciel lub jej pełnomocnik (nie musi to być profesjonalny pełnomocnik). Nie wydaje się także właściwe żądanie dodatkowej opłaty skarbowej od pełnomocnictwa w przypadku reprezentacji strony przez inną osobę (np. doradcę podatkowego). W takim wypadku wystarczające jest uiszczenie jednej opłaty skarbowej za występowanie w postępowaniu przed Ministrem Finansów (art. 6 ust. 1 pkt 4 i art. 8 ust. 1 ustawy o opłacie skarbowejej). Działania Rady nie kwalifikują się jako czynności w ramach odrębnego postępowania, chociaż tryb wydania opinii przypomina w niektórych aspektach postępowanie o wydanie interpretacji indywidualnej (wyznaczanie terminu na udzielenie wyjaśnień, 90-dniowy czas trwania procedury, do którego nie wlicza się okresu oczekiwania na uzupełnienie braków formalnych). Wedle art. 119i § 7 OP, członkowie Rady, niezgadzający się ze stanowiskiem zawartym w opinii Rady mogą wystąpić ze zdaniem odrębnym. Takie rozwiązanie przypomina tryb orzekania przez sądem (przykłado-

22 Ustawa z dnia 21 czerwca 1996 r. o urzędach i izbach skarbowych, Dz. U. z 2015 r. poz. 578. Poza organami podatkowymi należy wyróżnić także inne organy powołane do wykonywania funkcji podatkowych (art. 13a OP). W opinii M. Zdebel w przepisach szczególnych nadano pewne uprawnienia przysługujące organom podatkowym - Dyrektorowi Instytutu Sztuki Filmowej, Prezesowi Zarządu Narodowego Funduszu Ochrony Środowiska i Gospodarki Wodnej, Wojewodom M. Zdebel, [w:] H. Dzwonkowski (red.), Ordynacja podatkowa. Komentarz, Warszawa 2013, s. 99-100. Dlatego też formułowanie tezy, jakoby organem podatkowym był każdy organ posiadający uprawnienia związane z należnościami podatkowymi, jest bezpodstawne.

23 Ustawa z dnia 16 listopada 2006 r. o opłacie skarbowej, Dz. U. z 2015 r. poz. 783. 
wo art. 137 Prawa o postępowaniu przed sądami administracyjnymi ${ }^{24}$ ). Jest także potwierdzeniem tego, iż opinia Rady nie stanowi decyzji podatkowej, w której nie występuje instytucja zdania odrębnego. Brak jednak wydania opinii w ustawowym terminie będzie oznaczać zasadność zastosowania art. 119a OP. Tym samym, przewlekłość (lub bezczynność) Rady będzie powodem pogorszenia sytuacji strony. Taki przypadek nie nastąpi, gdy to strona wystąpiła $z$ wnioskiem o wydanie opinii przez Radę. Korzystniejsze wydaje się zatem inicjowanie przez stronę procedury sporządzenia opinii przez Radę, jednakże jest to wyłącznie możliwe w postępowaniu odwoławczym (gdy w I instancji wydano decyzję w sprawie określonej w art. 119g § $1 \mathrm{OP})$.

Uregulowanie ustawowe Rady należy uznać za właściwe działanie ustawodawcy, którego intencją wydaje się stworzenie organu niezależnego, złożonego $\mathrm{z}$ osób mających wiedzę, doświadczenie $\mathrm{i}$ autorytet $\mathrm{w}$ zakresie prawa podatkowego, systemu finansowego, rynków finansowych, obrotu gospodarczego lub międzynarodowego prawa gospodarczego. Świadczy to też o współpracy Ministra Finansów z przedstawicielami wymiaru sprawiedliwości (sędziowie, osoby wskazane przez Ministra Sprawiedliwości), środowiska akademickiego, doradców podatkowych oraz innych osób posiadających odpowiednią wiedzę do tego aby wydawać opinię jako ekspert prawa podatkowego (art. 119 o $§ 1$ pkt 1-7 OP). Pomimo że opinia Rady nie jest wiążąca dla organu rozstrzygającego, to jednak jej stanowisko ma kluczowe znaczenie dla przebiegu postępowania określonego $\mathrm{W}$ art. 119g-1191 OP. W świetle art. 194; art. 197 w zw. z art. 119 lit. 1 OP, opinii wydanej przez Radę nie można kwalifikować jako dowodu z opinii biegłego lub dokumentu urzędowego. Aby przeprowadzić pierwszy z wymienionych dowodów, organ powinien powołać biegłych w trybie art. $197 \S 1$ OP, zaś dokument urzędowy może być jedynie sporządzony przez organ administracji publicznej (jak zostało wyżej przedstawione, Rada nie jest takim organem). Właściwą podstawą do włączenia opinii wydanej przez Radę do akt sprawy jest art. 187 § 1 OP. Ponadto nieprawidłowe przeprowadzenie procedury pozyskania opinii w sprawie może być podstawą do wzruszalności ewentualnej decyzji podatkowej. Tym samym, Rada do Spraw Przeciwdziałania Unikaniu Opodatkowania jest ciałem doradczym, organem nieposiadającym uprawnień podatkowych (niebędącym organem podatkowym), którego działanie jest uregulowane ustawowo, przez co Rada pełni istotną

${ }^{24}$ Ustawa z dnia 30 sierpnia 2002 r. - Prawo o postępowaniu przed sądami administracyjnymi, Dz. U. z 2016 r. poz. 718. 
rolę $\mathrm{w}$ przeprowadzeniu prawidłowej procedury dotyczącej unikania opodatkowania przez stronę.

\section{Opinie zabezpieczające}

Ustawodawca podatkowy wprowadził szczególną procedurę uzyskiwania przez podatnika potwierdzenia legalności dokonywanych przez niego czynności w kontekście jego obowiązków podatkowych. Oznacza to, że podatnika, który wystąpił o wydanie opinii zabezpieczającej i ją uzyskał, nie mogą spotkać negatywne konsekwencje przewidziane dla podatników unikających opodatkowania (art. 119b § 1 pkt 2 OP). Jednocześnie pewne novum stanowi art. 14na pkt $1 \mathrm{OP}$, wedle którego ochrony prawnej związanej z interpretacją indywidualną nie stosuje się, gdy stan faktyczny lub zdarzenie przyszłe stanowi element czynności będącej przedmiotem decyzji wydanej zgodnie $\mathrm{z}$ art. 119a OP. W takim wypadku interpretacja indywidualna, nawet gdyby została wydana w sprawie rozstrzyganej przez Ministra Finansów (dotyczącej unikania opodatkowania), nie odniesie zamierzonego skutku dla podatnika. Oprócz interpretacji ogólnej, interpretacji indywidualnej, decyzji dotyczącej porozumienia w sprawach ustalenia cen transakcyjnych ustawodawca wprowadził opinie zabezpieczające jako urzędowe potwierdzenie właściwej wykładni przepisów podatkowych.

Wniosek o wydanie opinii zabezpieczającej musi zawierać elementy wymienione $\mathrm{w}$ art. 119x $\S 1$ OP. Spośród wskazanych w tym paragrafie danych, jakie należy zawrzeć, szczególną uwagę zwraca pkt 5 i 6 paragrafu, wedle którego wnioskodawca musi opisać ekonomiczne uzasadnienie przeprowadzanej czynności prawnej oraz określić jej skutki podatkowe, w tym korzyści na gruncie prawa podatkowego. Nie każda czynność prawna ma ekonomiczne uzasadnienie, co nie wyklucza, że jest ona niezbędna, rzeczywista i determinuje zaistnienie przychodu (lub dochodu) w przyszłości. Wedle art. 119w § 3 OP, opinia zabezpieczająca będzie wydana w stosunku do czynności planowanej, rozpoczętej lub zakończonej. W stosunku do transakcji łączonych wniosek będzie musiał zawierać opis wszelkich czynności, które łącznie ekonomicznie uzasadniają dokonanie pojedynczej czynności. Wniosek o wydanie opinii zabezpieczającejw kontekście wymogów określonych w art. 119x § 1 pkt 5 i 6 OP będzie wymagał od autora tego wniosku szerokiej wiedzy obejmującej przepisy podatkowe a także orzecznictwo sądów administracyjnych i wydane 
interpretacje organów podatkowych dotyczące przykładów „korzyści podatkowych” oraz determinantów uznania czynności za „ekonomicznie uzasadnioną" ${ }^{25}$. Analizując przepisy dotyczące trybu występowania o wydanie ww. opinii, należy zwrócić uwagę na pewne uchybienie ze strony ustawodawcy, który dopuścił złożenie niepoświadczonych kopii dokumentów przez osoby nieuprawnione w załączeniu do wniosku (art. 119x § 2 OP). Pomijając moc dowodową niepoświadczonej prawidłowo kopii, należy zastanowić się, na ile taka kopia jest dla organu wiarygodna, skoro nie ma potwierdzenia, że istniał oryginał. Logicznym rozwiązaniem wydaje się zastąpienie słowa "kopia”, użytego we wspomnianym przepisie, "odpisem” oraz odniesieniem do art. 194a § 2 OP. Wtedy organ podatkowy otrzymywałby tylko te dokumenty, które mogą być dowodem w sprawie i których zgodność z oryginałem została potwierdzona przez osobę uprawnioną (np. doradcę podatkowego, notariusza, adwokata).

$W$ procedurze wydania opinii zabezpieczającej wprowadzono elementy niewystępujące dotychczas w OP. Wedle art. 119x § 4 OP, rozpatrując wniosek, Minister Finansów może zorganizować spotkanie, na którym wyjaśnione zostaną zaistniałe wątpliwości dotyczące konkretnego wniosku. Takiego „spotkania” nie można kwalifikować jako rozprawy podatkowej (art. 200a-200d OP) bądź dowodu z zeznań świadka (art. 190; art. 195 w zw. z art. 181 OP). Nie stosuje się wtedy wobec strony art. 262 OP. Zgromadzone informacje należy przyrównać do oświadczenia strony, które zostało złożone bez rygoru odpowiedzialności karnej (a contrario art. $180 \S 2$ OP) i nie stanowi przesłuchania strony w trybie art. 199 OP. Celem spotkania z pracownikami Ministerstwa Finansów jest wyjaśnienie stanowiska wnioskodawcy w zakresie braku możliwej korzyści podatkowej i bardziej szczegółowe opisanie stanu faktycznego. Tego rodzaju postępowanie organu wydaje się pełnić rolę subsydiarną w stosunku do tradycyjnego wezwania pisemnego (art. 155 § 1 OP). Skierowanie do wnioskodawcy wezwania o wyjaśnienie konkretnych elementów wniosku wydaje się być zalecane dla celów dowodowych. Nie ma wymogu spisywania ze spotkania, o którym mowa $\mathrm{w}$ art. 119x $\S 4$ OP, protokołu lub adnotacji

${ }^{25} \mathrm{~W}$ przeszłości organy podatkowe wielokrotnie wypowiadały się o potencjalnych korzyściach podatkowych oraz braku ekonomicznego uzasadnienia dla dokonywanych przez podatników czynności będących w rzeczywistości obejściem prawa podatkowego. Przykładowo, interpretacje indywidualne: Dyrektora Izby Skarbowej w Poznaniu z dnia 13 maja 2015 r. (ILPB4/4510-72/15-2/DS.); Dyrektora Izby Skarbowej w Warszawie z dnia 17 grudnia 2014 r. (IPPB5/423-921/14-2/PS); Dyrektora Izby Skarbowej w Katowicach z dnia 5 stycznia 2015r. (IBPBI/2/423-1236/14/AP) i z dnia 13 maja 2016 r. (IBPB-1-1/4511-171/16/BK); Dyrektora Izby Skarbowej w Bydgoszczy z dnia 7 maja 2014 r. (ITPB3/423-64c/14/MK); Dyrektora Izby Skarbowej w Łodzi z dnia 10 października 2012 r. (IPTPP2/443-606/12-4/JN). 
urzędowych (art. 177 OP), chociaż wydaje się to wskazane. Może bowiem wyniknąć problem, gdy zarówno organ, jak i strona będą mieli rozbieżne zdanie dotyczące treści ustaleń na spotkaniu dotyczącym wydania opinii zabezpieczającej.

W założeniu, opinie zabezpieczające mają pełnić funkcje ochronne dla podatników, którzy chcą działać w sposób zgodny z prawem, ale wyrażają obawy, że tworzone przez nich konstrukcje prawne zostaną zweryfikowane negatywnie przez organy podatkowe. Przeszkodą w występowaniu o opinie zabezpieczające może być jednak relatywnie wysoka (i słusznie krytykowana) opłata za jej wydanie ${ }^{26}$. Może to wpłynąć na niewielkie zainteresowanie uzyskaniem takiej opinii. Należy przy tym pamiętać, że opinie zabezpieczające będą publikowane, istnieje zatem prawdopodobieństwo, że staną się swoistym drogowskazem dla podatników - jak planować czynności prawne. Powstaje jednak pytanie, w jakim stopniu w wydawanych przez Ministra Finansów opiniach zabezpieczających odnaleźć będzie można analogiczne stanowisko w podobnych merytorycznie sprawach. Nie ma regulacji prawnych, które by wiązały organ w zakresie przyszłych opinii, dlatego zasadne wydaje się rozważenie zmiany art. 119za poprzez wprowadzenie do przepisu ust. 2 o treści: „Minister Finansów wydaje opinie zabezpieczające, mając na względzie jednolity charakter stanowiska organu w podobnych sprawach". Należałoby także dokonać modyfikacji art. 119zd określając paragraf 3 tego przepisu jako: „Minister Finansów może z urzędu zmienić opinię zabezpieczającą gdy opinia ta narusza art. 119za ust. 2". Wtedy organ będzie musiał zwracać uwagę na to, aby wnioski o wydanie opinii były rozpatrywane w podobnych sprawach tak samo ${ }^{27}$. Umożliwi to pełniejszą realizację zasady pewności prawa podatkowego.

\section{Niektóre zagrożenia dla interesu podatnika}

Klauzula przeciwko unikaniu opodatkowania ma służyćjako narzędzie przeciwdziałające praktykom podatników, zamierzających osiągnąć wraz

${ }^{26}$ Zob. H. Filipczyk, Stosowanie klauzuli ogólnej przeciwko unikaniu opodatkowania - zagadnienia wybrane, "Monitor Podatkowy” 2016, nr 7, s. 13.

${ }^{27}$ B. Brzeziński wspomina o „zasadzie respektowania utrwalonej praktyki interpretacyjnej organów podatkowych" (B. Brzeziński, Reformy prawa podatkowego a kwestia wykładni prawa, [w:] H. Dzwonkowski, J. Kulicki (red.), Dylematy reformy systemu podatkowego w Polsce, Warszawa 2016, s. 271. 
z dokonaniem czynności prawnej konkretną korzyść (np. mniejszy ciężar podatkowy), mimo że ustawodawca podatkowy nie przewidział takiego przysporzenia ${ }^{28}$. Samo wprowadzenie przepisów dotyczących ogólnie określonych przesłanek uznania podejmowanych przez podatnika działań jako sztucznych, ekonomicznie nieuzasadnionych (przeprowadzanych celem uniknięcia opodatkowania) nie oznacza automatycznie, że status podatnika ulegnie pogorszeniu. Administracja skarbowa otrzymała od ustawodawcy narzędzie, które może być wykorzystane racjonalnie z pożytkiem zarówno dla budżetu państwa, jak i realizacji praw i obowiązków podatnika (argumentum ad iudicium). Podstawową funkcją klauzuli przeciwko unikaniu opodatkowania jest prewencja przed dokonywaniem przez podatników czynności o charakterze stricte optymalizacyjnym. Ustawodawca podatkowy wydaje się mieć świadomość tego, że wprowadzenie nowelizacji przepisów podatkowych obejmujących aktualne metody unikania opodatkowania jest pozbawione sensu, gdyż podatnicy (lub ich pełnomocnicy profesjonalni) szybko znajdą sposób na obejście rygorystycznych ram tego prawa. Dlatego też właściwym rozwiązaniem wydaje się klauzula, o ile jej stosowanie będzie ostatecznościa, a nie normą (gdy organ chce otrzymać większy podatek od podatnika). Należy zatem sformułować tezę, iż zagrożeniem dla interesu podatnika nie jest konkretnie wprowadzenie przepisów art. 119a-119zf $\mathrm{OP}$, lecz możliwa wykładnia contra legem tych przepisów. W takim wypadku niewłaściwe działania organu powinny być kwestionowane na etapie sądowej kontroli decyzji podatkowej.

Słusznym jest twierdzenie ${ }^{29}$, że obowiązywanie w polskim porządku prawnym klauzuli o unikaniu podwójnego opodatkowania będzie skutkować rozszerzeniem autonomii prawa podatkowego (zwłaszcza względem prawa cywilnego). Organ podatkowy może uznać, że cywilistyczne ujęcie czynności prawnej i zgodny zamiar stron nie mają żadnego znaczenia w kontekście badania pozorności, braku ekonomicznego uzasad-

${ }^{28}$ Zob. A. Olesińska, The General Anti-Avoidance Rule Consultative Committees, "Comparative Law Review" 2013, nr 16, s. 68; G.J. Leśniak, Koniec z agresywnym planowaniem podatkowym, „Radca Prawny” 2013, nr 137, s. 19. Klauzula ma uniemożliwić obliczenie podatku w sposób sprzeczny z prawem podatkowym, gdy stanowisko podatnika stoi w sprzeczności z treścią norm podatkowych. Szerzej o czynności sprzecznej z normami podatkowymi zob. R. Bernat, Odmowa dokonania czynności notarialnej sprzecznej z prawem podatkowym, „Forum Prawnicze" 2015, nr 4, s. 80-81.

${ }^{29}$ Taki pogląd wyraził m.in Prezes Rządowego Centrum Legislacji, Uzasadnienie projektu ustawy o zmianie ustawy - Ordynacja podatkowa oraz niektórych innych ustaw z dnia 13 maja 2016 r., data dokumentu: 1 marca 2016 r., s. 4, http://legislacja.rcl.gov.pl/ [dostęp: 25.07.2016 r.]. 
nienia dla tej czynności. Takie działanie organu może doprowadzić do pogwałcenia innych zasad prawa podatkowego. Jeśli organy podatkowe będą powszechnie stosowały tryb $\mathrm{z}$ art. $119 \mathrm{~g} \S 1$ OP celem kwestionowania pierwotnej wysokości zobowiązania podatkowego, to będzie to naruszało zasadę pewności prawa podatkowego. Należy to łączyć także z szerszym występowaniem ryzyka podatkowego ${ }^{30}$, rozumianego $\mathrm{w}$ tym wypadku jako brak pewności co do kwalifikacji czynności jako sztucznej, ekonomicznie nieuzasadnionej. Podatnicy, których czynności zostaną zakwestionowane, będą niesprawiedliwie opodatkowani w stosunku do podmiotów, niebędących stronami postępowań dotyczących unikania opodatkowania. Zdaniem niektórych ${ }^{31}$, wprowadzenie klauzuli przeciwko unikaniu opodatkowania przywróci naturalny stan równości podatników, w którym podmioty posiadają te same prawa i obowiązki, gdyż żaden z nich nie stosuje metod optymalizacyjnych (różnicujących stopień opodatkowania podatników). Jeśli system podatkowy stanie się represyjny wobec podatników, metody zagranicznej optymalizacji (spółki offshore, raje podatkowe) będą się cieszyły większą popularnością ${ }^{32}$. Alokacja kapitału przez spółki do innych krajów jest dostępna jedynie dla podmiotów, które posiadają odpowiednie środki do tego typu operacji. W odniesieniu do osób fizycznych (także mikroprzedsiębiorców) można wyrazić obawę, że skutki wprowadzenia klauzuli o unikaniu opodatkowania będą najbardziej dla nich odczuwalne. Podmioty zagraniczne, średni i duzi przedsiębiorcy mogą się starać stosować zagraniczne metody optymalizacyjne oraz dokonywać zmiany rezydencji podatkowej, podczas gdy podatnicy o niskim dochodzie pozostaną $\mathrm{w}$ ramach polskiej jurysdykcji.

Dodatkowo, ogólny charakter klauzuli może przyczynić się do tego, że dla organów podatkowych standardem stanie się stosowanie wy-

${ }^{30}$ Szerzej M. Stępień, Elementy zarządzania podatkami przedsiębiorstwa w aspekcie ryzyka podatkowego, „Zeszyty Naukowe Uniwersytetu Szczecińskiego nr 864. Finanse, rynki finansowe, ubezpieczenia" 2015, nr 1, s. 41. Zasada pewności prawa nie odnosi się wyłącznie do sfery podatków (zob. H. Filipczyk, Postulat pewności prawa w wykładni operatywnej prawa podatkowego, Warszawa 2013, s. 21 i n.). W omawianym przypadku dotyczy możliwości rozpoznania przez adresata normy prawnej możliwych skutków planowanej czynności w kontekście praw i obowiązków wynikających z prawa podatkowego.

31 A. Olesińska, Klauzula ogólna przeciwko unikaniu opodatkowania - moda czy konieczność?, „Infos BAS” z 10.03.2016 r., nr 5, s. 3.

${ }_{32}$ Zob. I. Kuchciak, Istota $i$ metody przeciwdziałania wykorzystaniu rajów podatkowych w polskich warunkach, "Acta Universitatis Lodziensis. Folia Oeconomica” 2007, nr 203, s. 261; A. Brodzka, Inicjatywy międzynarodowe w kierunku poprawy przejrzystości i bezpieczeństwa obrotu finansowego, "Nauki o finansach" 2013, nr 4, s. 107-109; P. Folfas, Przenoszenie działalności gospodarczej do rajów podatkowych jako strategia zarządzania finansami korporacji transnarodowych: motywy, formy, korzyści i zagrożenia, „Bank i Kredyt” 2008, nr 12, s. 23. 
kładni rozszerzającej33 przepisów mających wpływ na zakres opodatkowania. Nie ma bowiem gwarancji, że organy podatkowe nie otrzymają od Ministra Finansów wytycznych co do tego, jakie czynności traktowane są jako unikanie opodatkowania. Taki katalog będzie stanowił niejako pozaustawową listę czynności, z którymi związany jest obowiązek podatkowy. Wprowadzenie klauzuli umożliwia przedstawicielom administracji skarbowej pośredni wpływ na częstotliwość dokonywania poszczególnych czynności prawnych na terytorium Polski ${ }^{34}$. Jeśli Minister Finansów będzie wydawał decyzję w wyniku zastosowania art. 119g § 1 OP, w której zobowiązanie podatkowe ulegnie zwielokrotnieniu, to podatnicy moga pomijać stosowanie danej czynności prawnej, jaką podlegającej standardowo kwestionowaniu przez organy podatkowe lub kontroli skarbowej.

Warto zauważyć, że kwestionowanie przez Ministra Finansów wysokości pierwotnie obliczonego podatku w sposób określony w art. 119g § 1 OP, nie oznacza bezpośredniego wpływu na sytuację podatkową jedynie strony postępowania. W świetle art. 119j § 1 OP, podmiot inny niż strona, będący uczestnikiem czynności prawnej (przedmiot transakcji), której skutki podatkowe określone decyzją (art. 119g § 1 OP) może skorygować swoją deklarację, wystąpić z wnioskiem o stwierdzenie nadpłaty lub zwrot podatku. Ustawodawca wprowadził zatem uprawnienie, a nie przymus dotyczący osoby związanej ze strona, jednocześnie nie wskazując, jaką pozycję $\mathrm{w}$ postępowaniu posiadać będzie taki uczestnik czynności mającej na celu unikanie opodatkowania. Powstaje wątpliwość, skąd ma posiadać wiedzę dotyczącą rozstrzygnięcia w postępowaniu o unikanie opodatkowania osoba niebędąca stroną takiej procedury. Trudno oczekiwać, aby przedstawiciele organów podatkowych informowali osobę trzecią o treści decyzji, o której mowa w art. 119g § 1 OP.

Należy przyznać, że jednym z negatywnych dla podatnika skutków omawianej nowelizacji Ordynacji podatkowej będzie zmniejszenie liczby legalnych, stosowanych dotychczas metod optymalizacji podatkowej. Istnieje szereg sposobów, które umożliwiały - dochowując prawem przewidzianych obowiązków przez podatnika - zapłatę niższego podatku. Istnieje prawdopodobieństwo, że w praktyce organy podatkowe zrównają legalną optymalizację podatkową z przejawem unikania opodatkowa-

${ }^{33}$ Przeciwko wykładni rozszerzającej w prawie podatkowym wypowiadają się: Z. Kukulski, B. Wojciechowski, Kolizja zasad równości i pewności w prawie podatkowym a klauzula Łw. obejścia prawa podatkowego - uwagi krytyczne na tle art. 24b Ordynacji podatkowej, „Palestra" 2004, nr 5-6, s. 13.

${ }^{34}$ Podobnie W. Wyrzykowski, Optymalizacja podatkowa przedsiębiorców - granice prawa a granice bezpieczeństwa, „Zarządzanie i Finanse” 2015, nr 3, cz. 2, s. 48. 
nia $^{35}$. Wtedy podatnik utraci prawo wyboru charakteru czynności prawnej w kontekście jej podatkowych obciążeń. Jak zostało już wcześniej wspomniane, nie ma ustawowego obowiązku poszukiwania takich czynności cywilnoprawnych, które wiązałyby się z najwyższym możliwym obciążeniem podatkowym. Oznacza to, że przywilejem podatnika jest swobodne ustalanie charakteru czynności i pośredni wpływ na stopień obciążenia należnościami publicznoprawnymi. Jeśli klauzula stanie się narzędziem represyjnym, mającym służyć przede wszystkim funkcji fiskalnej, to swoboda podatnika w zakresie kształtowania cywilistycznego charakteru czynności zostanie znacznie ograniczona. Trudno bowiem uznać działanie podatnika za swobodne jeśli to administracja skarbowa decyduje, jakie czynności cywilne mają wydźwięk negatywny.

Kończąc temat zagrożeń dla interesu podatnika, warto wspomnieć o niepewnych (na chwilę obecną) skutkach, jakie wywierać będzie działalność Rady do Spraw Przeciwdziałania Unikaniu Opodatkowania. Z jednej strony jest to ciało niezależne od Ministra Finansów, które powinno wydawać opinie w oparciu o obowiązujący stan prawny (także w zakresie przepisów unijnych) mając na względzie ewentualne reperkusje dla podatników, zakwestionowania konkretnej metody powstawania korzyści podatkowej. Jeśli Rada będzie wydawać (upubliczniane) opinie, których treść stanowić będzie dla innych podatników wytyczne (jak dokonywać czynności niesprzecznych z literą prawa podatkowego) to może się to przyczynić do poprawy systemu poboru podatkowego oraz realizacji zasady pewności prawa podatkowego. Jeśli jednak nie będzie możliwie sformułowanie ogólnych przesłanek zawartych w opiniach Rady dotyczących przejawów unikania opodatkowania, to u podatników może wyniknąć wątpliwość, czy w ogóle jest możliwe wyznaczenie granicy pomiędzy do-

35 Także J. Iwin-Garzyńska, Optymalizacja podatkowa a rozwój przedsiębiorstw, „Zeszyty Naukowe WSB w Poznaniu", red. M. Dylewski, Finansowe i podatkowe aspekty rozwoju przedsiębiorczości w regionach, 2014, t. 52, nr 1, s. 65. Zdaniem M. Jamroży, przedsiębiorca ma prawo poszukiwać (w sposób legalny) najkorzystniejszego pod względem podatkowym rozwiązania i nie można traktować go wtedy automatycznie jako oszusta podatkowego (M. Jamroży, wypowiedź na I Debacie Podatkowej Przeciwdziałanie unikaniu opodatkowania, Warszawa, dnia 10 grudnia 2015 r., „Przegląd Podatkowy” 2016, nr 3, s. 9. Warto wspomnieć, że dotychczas nie stworzono jurydycznego katalogu czynności kwalifikujących się jako optymalizacja podatkowa, gdyż odróżnienie czynności dokonanej w ramach swobody umów od czynności podjętej jedynie w celu zmniejszenia obciążenia podatkowego jest niezwykle trudne. Przykładowo, K. Gruziel błędnie zakłada, że jednym z narzędzi optymalizacji podatkowej jest wybór formy zawieranej przez wspólników spółki (K. Gruziel, Istota i założenia optymalizacji podatkowej - wybrane aspekty , "Zeszyty Naukowe SGGW. Ekonomika i Organizacja Gospodarki Żywnościowej” 2009, nr 77, s. 179-183). 
konywaniem transakcji w ramach swobody umów a celowym działaniem o charakterze unikania opodatkowania.

\section{Zakończenie}

Ocena wprowadzenia klauzuli przeciwko unikaniu opodatkowania uzależniona jest od tego, czy punktem odniesienia jest interes podatnika czy administracji skarbowej. Podatnicy mogą odczuć większy ciężar opodatkowania oraz rezygnować z dotychczas stosowanych optymalizacji podatkowych. Organy podatkowe zaś otrzymają dodatkowe narzędzie służące wzruszalności ustalonego $\mathrm{w}$ drodze samoobliczenia wymiaru podatku. Wątpliwości może wzbudzać właściwa interpretacja zwrotów niedookreślonych oraz klauzul generalnych umieszczonych w art. 119a-119zf OP. Należy jednak przy tym zauważyć, że wątpliwości te mogą zostać usunięte $\mathrm{w}$ drodze wydawanych w przyszłości opinii zabezpieczających oraz prawidłowo prowadzonych postępowań podatkowych w trybie art. 119 lit. g do 119 lit. 1 (tj. z uwzględnieniem art. 2a OP). Nie ma ustawowego zakazu stosowania w postępowaniach dotyczących unikania opodatkowania zasady in dubio pro tributario. Ciężar wykazania braku ewentualnych wątpliwości spoczywa na organie podatkowym, a nie na podatniku, który podnosi taki zarzut ${ }^{36}$. Skoro wątpliwości w sprawie stanowią element stanu faktycznego i należy je uznać za kwestię abstrakcyjną to domaganie się wskazania dowodów (np. z dokumentu, zeznania świadka) na zaistnienie wątpliwości byłoby niewłaściwe.

Klauzula przeciwko unikaniu opodatkowania ma pełnić funkcję prewencyjną, sankcyjną oraz fiskalną. Jeśli administracja skarbowa w pierwszej kolejności będzie realizować funkcję fiskalną, to pobocznym skutkiem obowiązywania klauzuli będzie zmiana odbioru (przez podatników) polskiego systemu podatkowego jako nieprzyjaznego podatnikowi na system represyjny. Długofalowe skutki powstania represyjnego systemu podatkowego to wzrost popularności zagranicznych optymalizacji podatkowych, zmiana rezydencji podatkowej (na bardziej przyjazną podatnikowi) lub celowe działania przestępcze mające prowadzić do zmniejszenia ciężaru podatkowego u adresatów norm prawa podatkowego.

${ }^{36}$ A contrario Interpretacja ogólna Ministra Finansów z dnia 29 grudnia 2015 r., PK4.8022.44.2015, mofnet.gov.pl [dostęp: 10.08.2016 r.]. 
Należy jednak przyjąć (być może niesłusznie) domniemanie racjonalności przedstawicieli administracji skarbowej (a simile racjonalności ustawodawcy ${ }^{37}$ ). Zwalczanie przedsiębiorczości oraz ograniczenie jej swobody prawdopodobnie przyniesie skutek $\mathrm{w}$ postaci zmniejszonego obrotu (oraz dochodu) w przedsiębiorstwach. W takim wypadku finalnie wprowadzenie klauzuli odniosłoby rezultat przeciwny do planowanego. Mimo szeregu obaw należy jednoznacznie stwierdzić, że wypracowanie właściwego kształtu klauzuli może mieć miejsce jedynie w drodze praktycznego stosowania. Biorąc pod uwagę literalne brzmienie art. 119a-119zf OP należy stwierdzić, że taki kształt wprowadzonych przepisów nie przeczy osiągnięciu celu w postaci zwiększonych wpływów budżetowych z tytułu uniemożliwienia dokonywania czynności sprzecznych z prawem podatkowym (mając na względzie jedynie obniżenie ciężaru podatkowego). Błędne jest twierdzenie ${ }^{38}$, jakoby przeprowadzenie badań naukowych dotyczących wpływu klauzuli generalnych i zwrotów niedookreślonych dotyczących unikania opodatkowania mogło skutkować poprawnym ustaleniem kształtu klauzuli o unikaniu opodatkowania. Jeśli klauzula ta ma być prawidłowo stosowana przez organy podatkowe, to jej kształt (treść przepisu) może być poprawiana jedynie w trakcie rzeczywistego funkcjonowania klauzuli. Nikt nie powinien mieć złudzeń, że błędów w wykładni art. 119a-119zf OP można uniknąć. Jednocześnie, dokonując w przyszłości zmian legislacyjnych, wydaje się możliwe wypracowanie takiej formuły klauzuli o unikaniu opodatkowania, która stanowić będzie skuteczne narzędzie zwalczania nieuczciwych praktyk podatników, nie pogarszając przy tym sytuacji podatkowej rzetelnych adresatów norm podatkowych.

Słowa kluczowe: unikanie opodatkowania, opinia zabezpieczająca, Rada do Spraw Przeciwdziałania Unikaniu Opodatkowania

${ }^{37}$ O racjonalności ustawodawcy podatkowego zob. J. Brolik (red.), Pisma w sprawach interpretacji prawa podatkowego. Wyjaśnienia, postępowanie, orzecznictwo, Warszawa 2013, s. 27; A. Bielska-Brodziak, Interpretacja tekstu prawnego na podstawie orzecznictwa podatkowego, Warszawa 2009, s. 127-131; wyrok WSA w Bydgoszczy z 10 września 2013 r. (I SA/Bd 410/13); wyrok NSA z 28 czerwca 2016 r. (I GSK 1785/14); wyrok WSA w Olsztynie z 30 czerwca 2016 r. (II SA/Ol 784/16); CBOSA.

${ }^{38}$ I. Szczepańska, Klauzula obejścia prawa w Ordynacji podatkowej, „Przegląd Ustawodawstwa Gospodarczego" 2014, nr 6, s. 24. 


\section{Bibliografia}

Bernat R., Deregulacja zawodu doradcy podatkowego jako naruszenie interesu podatnika, „Studia Prawno-Ekonomiczne” 2014, t. 93.

Bernat R., Odmowa dokonania czynności notarialnej sprzecznej z prawem podatkowym, „Forum Prawnicze” 2015, nr 4.

Bielska-Brodziak A., Interpretacja tekstu prawnego na podstawie orzecznictwa podatkowego, Warszawa 2009.

Brodzka A., Inicjatywy międzynarodowe w kierunku poprawy przejrzystości i bezpieczeństwa obrotu finansowego, „Nauki o Finansach” 2013, nr 4.

Brolik J. (red.), Pisma w sprawach interpretacji prawa podatkowego. Wyjaśnienia, postepowanie, orzecznictwo, Warszawa 2013.

Bryndziak S., Nadużywanie przepisów umów o unikaniu podwójnego opodatkowania przez transfer rezydencji podatkowej, "Zeszyty Naukowe Uniwersytetu Szczecińskiego nr 818. Finanse, rynki finansowe, ubezpieczenia" 2014, nr 68.

Brzeziński B., Zagadnienie konstytucyjności klauzuli normatywnej zapobiegającej unikaniu opodatkowania, [w:] P. Kardas, T. Sroka, W. Wróbel (red.), Państwo prawa i prawo karne. Księga jubileuszowa Profesora Andrzeja Zolla, Warszawa 2012.

Brzeziński B., Olesińska A., Klauzula normatywna zapobiegania unikaniu opodatkowania, [w:] B. Brzeziński (red.), Prawo podatkowe. Teoria, instytucje, funkcjonowanie, Toruń 2009.

Choduń A., Gomułowicz A., Skoczylas A., Klauzule generalne i zwroty niedookreślone w prawie podatkowym $i$ administracyjnym. Wybrane zagadnienia teoretyczne i orzecznicze, Warszawa 2013.

Duży J., Zorganizowana przestępczość podatkowa w Polsce. Zwalczanie przestępnego nadużycia mechanizmów podatków VAT i akcyzowego, Warszawa 2013.

Duda M., Uwarunkowania i zakres nowelizacji ustawy o podatku od towarów i ustug $w$ dobie kryzysu finansowego, „Studia Prawnicze KUL” 2014, nr 2.

Dzwonkowski H. (red.), Ordynacja podatkowa. Komentarz, Warszawa 2013.

Dzwonkowski H., Kulicki J. (red.), Dylematy reformy systemu podatkowego $w$ Polsce, Warszawa 2016.

Etel L. (red.), Ordynacja podatkowa. Kierunkowe założenia nowej regulacji, Białystok 2015.

Filipczyk H., Postulat pewności prawa w wykładni operatywnej prawa podatkowego, Warszawa 2013.

Filipczyk H., Stosowanie klauzuli ogólnej przeciwko unikaniu opodatkowania - zagadnienia wybrane, "Monitor Podatkowy” 2016, nr 7.

Folfas P., Przenoszenie działalności gospodarczej do rajów podatkowych jako strategia zarządzania finansami korporacji transnarodowych: motywy, formy, korzyści i zagrożenia, „Bank i Kredyt” 2008, nr 12.

Gołębiowski G., Dzwonkowski H. (red.), Zmiany w Ordynacji podatkowej. Poprawa jakości i uproszczenia. Konferencja, Warszawa 2013. 
Gomułowicz A., Aspekty ustrojowe opodatkowania, [w:] T. Dobrowska-Romanowska, A. Jankiewicz (red.), Konstytucja, ustrój, system finansowy państwa. Ksiega pamiatkowa ku czci prof. Natalii Gajl, Warszawa 1999.

Gomułowicz A., Małecki J., Podatki i prawo podatkowe, Warszawa 2010.

Gordon M., Klauzula przeciwko unikaniu opodatkowania w założeniach projektu zmiany Ordynacji podatkowej z kwietnia 2014 roku, "Roczniki Naukowe Wyższej Szkoły Bankowej w Toruniu" 2013, nr 12.

Gruziel K., Istota i założenia optymalizacji podatkowej-wybrane aspekty, "Zeszyty Naukowe SGGW. Ekonomika i Organizacja Gospodarki Zywnościowej" 2009, nr 77.

Hybka M.M., Możliwości zapobiegania agresywnemu planowaniu finansowego, „Kwartalnik Kolegium Ekonomiczno-Społecznego. Studia i Prace” 2015, nr 3, t. 4 .

Iwin-Garzyńska J., Optymalizacja podatkowa a rozwój przedsiębiorstw, "Zeszyty Naukowe WSB w Poznaniu", red. M. Dylewski, Finansowe i podatkowe aspekty rozwoju przedsiębiorczości w regionach, 2014, t. 52, nr 1.

Kalinowski M., Granice legalności unikania opodatkowania w polskim systemie podatkowym, Toruń 2001.

Kaliński M., Rozwój zasobów ludzkich w administracji podatkowej, "Zarządzanie Zasobami Ludzkimi" 2011, nr 5.

Karwat P., Obejście prawa podatkowego, Warszawa 2003.

Kostecki A., Klauzule generalne zapobiegania obejścia prawa podatkowego w niemieckiej doktrynie i regulacjach prawnych, [w:] W. Miemiec (red.), Księga jubileuszowa profesora Ryszarda Mastalskiego. Stanowienie $i$ stosowanie prawa podatkowego, Wrocław 2009.

Kowalczyk M., Prawo podatkowe - wróg czy sprzymierzeniec przedsiębiorcy, "Zeszyty Naukowe Uniwersytetu Szczecińskiego nr 864. Finanse, rynki finansowe, ubezpieczenia" nr 76, t. 1.

Krajewska A., P. Krajewski P., Rozkład obciązeń podatkowych w Polsce, "Acta Universitatis Lodziensis. Folia Oeconomica" 2011, nr 248.

Kuchciak I., Istota $i$ metody przeciwdziałania wykorzystaniu rajów podatkowych w polskich warunkach, "Acta Universitatis Lodziensis. Folia Oeconomica” 2007.

Kukulski Z., Wojciechowski B., Kolizja zasad równości i pewności w prawie podatkowym a klauzula tzw. obejścia prawa podatkowego - uwagi krytyczne na tle art. $24 b$ Ordynacji podatkowej, „Palestra” 2004, nr 5-6.

Kunysz J., Wójt, burmistrz, prezydent miasta jako organ podatkowy (wybrane zagadnienia), „Administracja: Teoria, Dydaktyka, Praktyka” 2012, nr 2.

Leśniak G.J., Koniec z agresywnym planowaniem podatkowym, "Radca Prawny" 2013, nr 137.

Litwińczuk H., Obejście prawa podatkowego w świetle doświadczeń międzynarodowych, "Przegląd Podatkowy" 1999, nr 9. 
Maj I., Unikanie opodatkowania w korporacjach międzynarodowych, [w:] M. Sadowski, A. Spychalska, K. Sadowa (red.), Acta Erasmiana VI. Ze studiów nad prawem, administracja i ekonomia, Wrocław 2014.

Mariański A., Rozstrzyganie watpliwości na korzyść podatnika. Zasada prawa podatkowego, Warszawa 2011.

Mączyński D., Wpływ orzecznictwa Trybunału Konstytucyjnego na trwałość instytucji materialnego prawa podatkowego, "Ruch Prawniczy, Ekonomiczny i Socjologiczny" 2014, z. 3.

Modzelewski W. (red.), Wstęp do nauki polskiego prawa podatkowego, Warszawa 2010.

Napiórkowska A., Czy ktoś broni podatnika?, „Studia Finansowoprawne”, red. P. Borszkowski, A. Huchla, E. Rutkowska-Tomaszewska, Podatnik versus organ podatkowy, 2011, nr 2.

Olesińska A., Klauzula ogólna przeciw unikaniu opodatkowania, Toruń 2013.

Olesińska A., Klauzula ogólna przeciwko unikaniu opodatkowania - moda czy konieczność?, „Infos BAS” z 10.03.2016 r., nr 5.

Olesińska A., Konstrukcja i funkcjonowanie klauzuli ogólnej zapobiegającej unikaniu opodatkowania w prawie podatkowym Kanady, „Kwartalnik Prawa Podatkowego" 2010, nr 2.

Olesińska A., The General Anti-Avoidance Rule Consultative Committees, "Comparative Law Review" 2013, nr 16.

Raczkowski K., Krukowski A., Optymalizacja podatkowa w teorii i praktyce zarzadzania wiedza bezpieczeństwa ekonomicznego, „Monitor Prawa Celnego i Podatkowego" 2010, nr 8.

Radwan A., Podatki w rolnictwie i leśnictwie - przewidywane kierunki zmian, „Folia Universitatis Agriculturae Stetinensis" 2007, nr 49.

Spoz A., Wybrane metody optymalizacji podatkowej przedsiębiorstw, "Zeszyty Naukowe Uniwersytetu Szczecińskiego. Finanse, rynki finansowe, ubezpieczenia" 2012, nr 52.

Stępień M., Elementy zarządzania podatkami przedsiębiorstwa w aspekcie ryzyka podatkowego, "Zeszyty Naukowe Uniwersytetu Szczecińskiego nr 864. Finanse, rynki finansowe, ubezpieczenia" 2015, nr 1.

Szczepańska I., Klauzula obejścia prawa w Ordynacji podatkowej, „Przegląd Ustawodawstwa Gospodarczego" 2014, nr 6.

Szczepański J., Unikanie opodatkowania w świetle orzecznictwa niemieckiego, „Ruch Prawniczy, Ekonomiczny i Socjologiczny” 2014, z. 1.

Teszner K., Administracja podatkowa i kontrola skarbowa w Polsce, Warszawa 2012.

Tołwińska A., Zarządzanie wiedza w urzędach kontroli skarbowej z punktu widzenia sprawnej ochrony interesów fiskalnych państwa, "Ekonomia i Zarządzanie" 2015, nr 1.

Wrzesińska-Nowacka A., Granice między unikaniem opodatkowania a uchylaniem się od niego na tle wybranych orzeczeń sądów administracyjnych, [w:] M. Mün- 
nich, A. Zdunek (red.), Stanowienie i stosowanie prawa podatkowego w Polsce. Optymalizacja podatkowa a obejście prawa podatkowego, Lublin 2012.

Wyciślok J., Optymalizacja podatkowa. Legalne zmniejszanie obciązeń podatkowych, Warszawa 2013.

Wyrzykowski W., Optymalizacja podatkowa przedsiębiorców - granice prawa a granice bezpieczeństwa, "Zarządzanie i Finanse” 2015, nr 3, cz. 2.

\section{LEGAL CHARACTER OF ANTI-AVOIDANCE TAXING CLAUSE}

\section{$\mathrm{S} \mathbf{u} \mathbf{m} \mathbf{m}$ a $\mathbf{r} \mathbf{y}$}

The clause against tax avoidance is a tax authorities' tool for fight improper attitudes taxpayers who want to reduce the legal tax burden. The author's task was to present the legal nature of the provisions (dealing with clause) made in July 2016 and the possible negative effects in the context of taxpayer's interest. As a result of undertaken examinations it was assumed that the recalled clause was performing the preventive, punishing and fiscal function. Entered recipes concerning tax avoidance can bring the positive result if given protecting opinions and conducted proceedings in the matter by the Minister of Finance aren't disturbing statutory rights and duties of the taxpayer. However there is concern that the introduction of the clause prevents the use of legitimate methods of reducing the tax burden and impact negatively on the freedom of shaping by the parties to the legal relationship. As a de lege ferenda postulate, it was considered the need for legislative changes in the field of Articles $119 \mathrm{za}$ and $119 \mathrm{zd}$ Tax Ordinance, which is intended to allow the behavior of the Minister of Finance single position, issuing opinions in similar cases.

Key words: avoidance of taxing, protecting opinion, Counsel of counteractions for avoiding taxing

\section{ПРАВОВАЯ ПРИРОДА ПОЯОЖЕНИЙ ПРОТИВ УКЯОНЕНИЯ ОТ ОПЛАТЫ НАЯОГОВ}

$$
\text { P е } 3 \text { г м е }
$$

Положения против уклонения от оплаты налогов является инструментом для налоговой администрации, которая служит противодействию активности налогоплательщика, который пытается незаконно уменьшить налоговое бремя. Целью автора было предоставить правовою природу введенных в июле 2016 года положение, а также возможных, негативных последствий, которые возникнут с контекста защиты интересов налогоплательщика. В результате проведенных исследований принято, что указанные договорные положения исподняют превентив- 
ную, санкционную и фискальную функции. Введенные положения касательно уклонения от оплаты налогов могут принести положительные результаты, если выдаваемые распоряжения, которые обеспечивают, а также проводены по делу Министром Финансов, процессы не будут нарушать законные права и обязанности налогоплательщика. Тем не менее, существует опасение, что введение указанные выше положений препятствует использованию законных методов снижения налогового бремени и негативно повдияет на свободу формирования правовых отношений сторон. Как заявления de lege ferenda признана необходимость законодательных изменений касательно ст. 119 бук. zа и 119 бук. zd Закона о налоге, который должен дать возможность сберечь единомышленною позицию Министра Финансов, который выдает распоряжения, которые обеспечивают в подобных делах.

Ключевые слова: уклонение от оплаты налогов, распоряжение, которое обеспечивает, Совет касательно дел противодействия по уклонению от оплаты налогов 